\title{
Research on the Industrial Structure Upgrading Effect of the Employment Mobility of Graduates from China's “Double First-Class" Colleges and Universities
}

\author{
Yilin Zhao ${ }^{1}$ (D) Feng $\mathrm{He}^{1,2, *}$ and Ying Feng ${ }^{1}$ \\ 1 School of Economics and Management, University of Science and Technology Beijing, Beijing 100083, China; \\ zhaoyilin218@163.com (Y.Z.); bkyingfeng@163.com (Y.F.) \\ 2 School of Economics and Management, Hubei Normal University, Huangshi 435002, China \\ * Correspondence: hefeng@manage.ustb.edu.cn
}

Citation: Zhao, Y.; He, F.; Feng, Y. Research on the Industrial Structure Upgrading Effect of the Employment Mobility of Graduates from China's

“Double First-Class" Colleges and Universities. Sustainability 2022, 14 2353. https://doi.org/10.3390/ su14042353

Academic Editor: Luigi Aldieri

Received: 10 October 2021

Accepted: 16 February 2022

Published: 18 February 2022

Publisher's Note: MDPI stays neutral with regard to jurisdictional claims in published maps and institutional affiliations.

Copyright: (C) 2022 by the authors. Licensee MDPI, Basel, Switzerland. This article is an open access article distributed under the terms and conditions of the Creative Commons Attribution (CC BY) license (https:// creativecommons.org/licenses/by/ $4.0 /)$.

\begin{abstract}
This paper develops a panel data fixed effect model to analyze the impact of the employment mobility of "Double First-class" college graduates on the rationalization of the industrial structure, advanced industrial structure, high-tech industrial structure upgrading, and industrial structure upgrading of the producer service industry. The results show that the mobility of graduates from "Double First-class" colleges and universities has a positive effect on upgrading the industrial structure of various provinces. The difference is that the mobility of "Double First-class" college graduates has a greater impact on the upgrading of the industrial structure of high-end producer services, but has a weaker impact on the structural upgrading of high-tech industries. There is a mismatch between the employment needs of "Double First-class" college graduates and the jobs provided by high-tech industries. The mobility of graduates from "Double First-class" colleges and universities has obvious differences in the promotion of industrial structure upgrading in different regions. Therefore, this paper proposes to increase investment in high-level human capital to promote the free flow of labor and other production factors across industries, sectors, and regions.
\end{abstract}

Keywords: industrial structure; graduates of China's "Double First-class" colleges and universities; employment mobility

\section{Introduction}

China has gone through three industrial structural changes since the 1950s. Changes in the industrial structure directly determine the speed of China's economic growth. Marx's reproduction theory is the foundation for industrial structure adjustment [1]. Industrial structure refers to the composition of various industries and the proportional relationship between them. Industrial structure upgrading is a systematic project that realizes the improvement of production factors, the optimization of the industrial structure, and the increase of industrial added value through the mutual transformation of production factors within the industry and between industries in terms of time, space, and levels. The optimization and upgrading of the industrial structure is the organic unity of the rationalization and advancement of the industrial structure. Industry and urbanization continue to be important drivers of China's economic growth. The service industry's share of GDP will gradually rise, and it will play an increasingly important role in economic growth. In the future, increasing the relative labor productivity of service industries and industries is an unavoidable choice for China's economic development [2].

Changes in a region's industrial structure are typically linked to consumer demand, factor endowments, and technological progress. According to Justin Yifu Lin's theory of new structural economics, upgrading the industrial structure depends on upgrading the factor endowment structure. The factor endowment structure mainly includes natural resources, material capital, labor, technology, infrastructure, and institutions. Human capital 
is an important foundation for transforming the industrial structure and a key determinant of economic growth [3]. The effective supply of human capital can accelerate industrial transformation and reduce the economic shock caused by industrial structure transformation [4]. China has a large population base, but the overall level of human capital is low. There has been a long-term mismatch between human capital and industrial structure in China, particularly a scarcity of high-quality talent in high-tech and high-end productive service industries. Young people will be impacted by the decision to leave to pursue higher education or employment, resulting in an outward migration trend and the loss of human capital [5]. Human capital structure advancement promotes technological transformation and upgrading to achieve high-quality economic development. To achieve the goal of industrial upgrading, we must increase factor endowments and capital accumulation, particularly human capital. "Double First-class", the abbreviation for world-class universities and disciplines, is a major strategic decision made by the CPC Central Committee and the State Council. It is also another national strategy in China's higher education field after the "211 Project" and "985 Project". There are 137 "Double First-class" universities in the first batch, including 42 world-class universities (36 in class A and 6 in class B) and 95 worldclass discipline universities. The "Double First-class" construction is predicated on the development of first-class disciplines. The foundation of first-class disciplines is superior discipline knowledge, and the foundation of discipline development is human creativity. First-class disciplines have outstanding academic leaders and teams, adequate academic funding and advanced scientific research equipment, as well as outstanding academic accomplishments and talent development quality [6]. First-class universities and first-class disciplines are critical drivers of knowledge discovery and scientific and technological innovation, a source of advanced ideas and excellent culture, a foundation for cultivating all types of high-quality talent, and a critical support for economic and social development. The Ministry of Education requires colleges and universities to focus on talent training when formulating construction plans, optimize the structure and layout of discipline construction, and reflect the core position of talent training in resource allocation and policy orientation. "Double First-class" college graduates belong to high-quality human capital. Therefore, the mobility of "Double First-class" college graduates will inevitably impact the upgrading of the industrial structure. This paper analyses whether China's high-quality human capital structure can promote the upgrading of the industrial structure, based on the theory that the factor endowment structure is endogenous to the industrial structure.

The coordinated development of high-quality talents and upgrading industrial structures is the key to sustainable urban development. China's regional economic development is not balanced. The distribution of university resources is also where there are more in the east than the west. This article attempts to answer the following questions: Has high-quality human capital promoted the upgrading of China's industrial structure? From a regional perspective, what are the differences in the impact of the unbalanced spatial distribution of high-quality human capital and structure on upgrading regional industrial structure? What steps should China take to optimize its human capital structure to meet the needs of industrial structure upgrading? These are critical theoretical and practical issues that must be thoroughly researched.

The structure of this paper is as follows: Section 2 presents an overview of related literature and formulates research hypotheses. Section 3 describes the data, sample selection, variables, and our estimation approach. Section 4 presents and discusses regression results and robustness checks. Section 5 discusses the heterogeneous regression results. The final section summarizes the research results and provides policy recommendations, in addition to outlining future areas of research.

\section{Literature Review}

The main objective of this paper is to investigate the impact of high-quality human capital on the upgrading of industrial structures. First and foremost, this research examines the employment mobility characteristics of "Double First-class" college graduates. Human capital 
has an impact on the modernization of regional industrial structures. Studying the employment mobility characteristics of "Double First-class" college graduates can grasp the regional employment distribution as a whole, paving the way for regional complexity analysis.

Second, human capital is a significant factor influencing industrial structure upgrading. Meanwhile, an advanced human capital structure is conducive to high-quality regional economic development. According to Lin Yifu's theoretical framework of new structural economics, the industrial structure is endogenous to the factor endowment structure. As a result, this article investigates the relationship between human capital and industrial structure upgrading and factor endowments and industrial structure upgrading.

\subsection{Characteristics of Graduates from "Double First-Class" Colleges and Universities' Employment Mobility}

The mobility of college graduates in China can be divided into five modes: immobility, early stage mobility, late-stage mobility, continuous mobility, and return mobility [7]. Rural areas and towns have limited ability to absorb graduates. In central and western regions, graduates are still "peacocks flying southeast" [8]. Most migrants move into several major urban agglomerations in the eastern coastal region and provincial inland capitals. College graduates tend to have peer mobility (returning to urban employment at the same level as the city of origin), and family background will promote peer mobility [9].

The mobility of college graduates is highly regional [10-12]. Although university graduates are extremely mobile, most will not leave their field of study within 10 years after graduation [13]. College graduates are much more mobile than non-university graduates $[14,15]$. This difference is since college graduates are more sensitive to employment opportunities in other fields. The educational structure and the quality of the university will affect the migration of graduates [16].

Labor mobility will promote innovation [17]; meanwhile, regional innovation vitality is affected by the mobility of human capital between regions [18]. Moreover, female graduates are generally more mobile than male graduates [19]. Individuals with higher levels of human capital are more geographically mobile [20]. The inter-regional mobility of human resources is mainly caused by the uneven distribution of universities across the country and the socio-economic differences between regions [21,22].

\subsection{Human Capital and Industrial Structure Upgrading}

Human capital has the effect of pushing the transformation of industrial structure [23]. Human capital is a highly mobile element [24]. The mobility of human capital is regional, and the mobility of human capital affects regional economic development $[25,26]$. As a carrier of technological progress, human capital will induce technological innovation through "learning by doing" and knowledge spillover and promote the introduction and absorption of technology $[27,28]$. Therefore, the higher the level of human capital, the more conducive to transforming the industrial structure. Higher levels of human capital can help society establish a new supply demand relationship between industries as soon as possible and restore a new supply demand balance. Moreover, it would ease the economic fluctuations caused by the breakdown of industrial linkages [29]. A simple increase in human capital does not necessarily cause economic growth. The human capital that matches the transformation of the industrial structure is the source of economic growth [30].

\subsection{Factor Endowments and Industrial Structure Upgrading}

At each point in time, the industrial structure of an economy is endogenous to the endowment and structure of production factors given by the economy then. The endowment of production factors and structural changes will promote the transformation of industrial structure [31]. From a dynamic point of view, the driving force of industrial growth generally comes from labor factors and then gradually comes from physical capital, human capital, knowledge capital, and technological progress [32]. Endowment structure significantly enhances the promotional role of technology innovation on industrial structure upgrading [33]. Related 
scholars propose a theory of endowment-driven structural change by developing a tractable growth model with infinite industries [34]. As argued in the new structural economics, the factor endowment structure in an economy determines its optimal industrial structure [35].

In the past, scholars mostly focused on the research on the coordinated development of industrial structure and employment structure, and most of the research perspectives focused on a certain province. Different scholars hold different opinions on the research of technological progress, industrial structure upgrading, and employment relations. Some scholars believe that upgrading the industrial structure based on technological innovation and the transformation of economic growth mode can promote employment. However, some believe that upgrading the industrial structure based on technological progress hurts employment. Regarding the research on technological progress, industrial structure upgrading, and employment of college graduates, most of the literature studies the employment of college graduates with a background in industrial structure upgrading. Most scholars study the adjustment of traditional industrial structures. Based on this article based on the data of the geographical mobility of employment of "Double First-class" college graduates from 2014 to 2019, this paper studies the impact of the graduate employment mobility of "Double First-class" colleges and universities on the rationalization of industrial structure, advanced industrial structure, high-tech industrial structure upgrading, and industrial structure upgrading of the producer service industry. The research object of this article focuses on high-quality college graduates, and the research is time-sensitive and pertinent.

There is limited domestic research on how "Double First-class" college and university graduation affect industrial upgrading. Most domestic and international studies are based on the broad concept of human capital. There is limited literature focusing on high-quality human capital. Moreover, most scholars in the United States and abroad study the characteristics of the mobility of college graduates. However, they are unrelated to the industrial structure. This article studies the impact of "Double First-class" college graduates' employment mobility on upgrading industrial systems, that is, the impact of high-quality human capital on the upgrading of the industrial structure. The research objects of this article are more detailed and targeted, providing literature support for future research in related fields.

\section{Measurement Model Construction}

\subsection{Model Construction, Variable Selection, and Measurement}

This paper uses the panel data of the employment mobility of "Double First-class" college graduates from 2014 to 2019 (hereinafter referred to as the employment mobility of college graduates) to conduct research. Panel data models include mixed regression, random-effects, and fixed-effects models. Through the Hansman test of each model, this paper uses a fixed-effect model to analyze the relationship between the employment mobility of college graduates and the upgrading of the industrial structure. Based on previous research experience [36,37], the benchmark regression model designed in this paper for the upgrading of the mobility of college graduates to the industrial structure is as follows:

$$
\text { structure }_{i t}=\alpha_{0}+\beta_{1} \text { mobility }+\delta \text { control }_{i t}+\varepsilon_{i t}
$$

Among them, " $i$ " represents the region, " $t$ " represents the time, and "structure" is the explained variable, which represents the industrial structure. "mobility" is the core explanatory variable, which represents the proportion of the number of college graduates in the total employment. "control" represents a series of control variables. Combining existing research literature, the control variables selected in this paper are urbanization rate, fiscal decentralization, degree of opening to the outside world, fixed asset investment, technological innovation, and infrastructure level. " $\varepsilon$ " represents the error term.

\subsection{The Explained Variable}

There are three explanatory variables in this article, namely, rationalization of industrial structure (Stru1), advanced industrial structure (Stru2), structural characteristics of high-tech industries (Stru3), and structural characteristics of producer services (Stru4). 
The rationalization of industrial structure refers to the quality of aggregation between industries. It is not only a reflection of the degree of coordination between industries but also a reflection of the degree of effective use of resources [38]. It measures the degree of coupling between factors' input and output structures. The formula is:

$$
E=\sum_{i=1}^{3} y_{i, m, t} \cdot \ln \left(y_{i, m, t} / l_{i, m, t}\right), m=1,2,3
$$

Among them, $y_{i, m, t}$ represents the proportion of the m-th industry in the $i$ region to the regional GDP during the $t$ period. $l_{i, m, t}$ represents the proportion of employees in the $m$-th industry in the $i$ region in the total employed persons during the period $t$.

The advancement of the industrial structure refers to regular changes in the industrial structure as the economy continues to grow. The main manifestation is that the proportion of the tertiary industries continues to rise in the order of the primary, secondary, and tertiary industries. According to the division of three industries, GDP is divided into three parts. The proportion of the added value of each part in GDP is used as a component in the space vector. Thus, forming a set of three-dimensional vectors $X_{0}=\left(x_{1,0}, x_{2,0}, x_{3,0}\right)$. Then, calculate the angles $\omega_{1}, \omega_{2}, \omega_{3}$ between $X_{0}$ and the vectors $X_{1}=(1,0,0), X_{2}=(0,1,0)$, $X_{3}=(0,0,1)$ :

$$
\theta_{j}=\arccos \frac{\sum_{i=1}^{3}\left(x_{i, j} \cdot x_{i, 0}\right)}{\sum_{i=1}^{3}\left(x_{i, j}^{2}\right)^{1 / 2} \cdot \sum_{i=1}^{3}\left(x_{i, 0}^{2}\right)^{1 / 2}}, j=1,2,3
$$

The formula for advanced industrial structure is [39]:

$$
W=\sum_{k=1}^{3} \sum_{j=1}^{k} \omega_{j}
$$

The structural characteristics of the high-tech industry are expressed by the proportion of high-tech manufacturing in the total manufacturing output. According to the 2017 Notice of the National Bureau of Statistics on the issuance of the "High-tech Industry (Manufacturing) Classification (2017)", high-tech industries (manufacturing industries) include pharmaceutical manufacturing, aviation, spacecraft and equipment manufacturing, electronic and communication equipment manufacturing, computer and office equipment manufacturing, medical equipment and instrumentation manufacturing, and information chemical manufacturing.

The structural characteristics of the producer service industry are expressed by the ratio of the high-end producer service industry to the low-end producer service industry [40]. According to the 2014 "Guiding Opinions of the State Council on Accelerating the Development of the Producer Service Industry to Promote the Adjustment and Upgrade of Industrial Structure" and the "Notice of the State Council on Issuing the Twelfth Five-Year Plan for the Development of the Service Industry", the scope of the productive service industry includes R\&D, design and other technical services for production activities, cargo transportation warehousing and postal express services, information services, financial services, energy conservation and environmental protection services, productive leasing services, business services, human resources management and training services, wholesale brokerage agency services, and product support services.

\subsection{Core Explanatory Variables}

The core explanatory variable is the proportion of the total number of college graduates in the total number of urban employments after the employment mobility.

The formula is:

$$
\text { Mobility }=\frac{\text { The total number of graduates after the migration of employment }}{\text { The total urban employment }}
$$

The total number of graduates from the province's colleges and universities after the migration of employment in that year $=$ the number of graduates employed in the 
province in that year + the number of graduate employment inflows into the province that year - the number of graduate employment outflows from the province that year. The comparison between the total number of college graduates in the province after the migration of employment and the number of graduates before that year shows whether the province's graduates have a net inflow or a net outflow.

\subsection{Control Variable}

Combined with the existing research literature, there are 5 control variables added in this paper. Urbanization rate (Urban), measured by the proportion of the urban population in the total population. Urbanization is an important way to promote the transformation and upgrading of China's industries [41]. Fiscal decentralization (Fiscal) is expressed as the percentage of each province's per capita fiscal expenditure in the central per capita fiscal expenditure. Chinese-style decentralization is an important factor hindering the upgrading of the industrial structure [42,43]. The degree of opening to the outside world (Open) is expressed in terms of the actual use of FDI. The literature shows that foreign direct investment is an important factor affecting the upgrading of the industrial structure [44]. The actual utilization of FDI refers to foreign capital that arrives after China signs a contract with a foreign company. Only the actual utilization of FDI can truly reflect the level of foreign capital utilization. Fixed asset investment (Fix), using the data published in the National Statistical Yearbook for analysis. Infrastructure level (Infra), measured by road mileage per square kilometer. Infrastructure will promote the upgrading of the industrial structure through spatial spillover effects and the Tibbert mechanism [45]. Technological innovation (Tech) is measured by the number of patent applications accepted. Technological innovation has a positive impact on the upgrading of the industrial structure [46].

\subsection{Data Sources and Descriptive Statistics}

The data used in this study are collected from the "Graduate Employment Quality Report" of 26 provinces (municipalities and autonomous regions) in eastern, central, and western China from 2014 to 2019. A total of 137 "Double First-class" colleges and universities have been counted, compiled, and calculated based on the data of the "China Statistical Yearbook" and provincial statistical yearbooks, "China Science and Technology Statistical Yearbook", and "China High-tech Industry Statistical Yearbook". Table 1 is the descriptive statistics of the data.

Table 1. Variable descriptive statistics.

\begin{tabular}{|c|c|c|c|c|c|}
\hline Variable Name & Obs & Mean & Std. Dev. & Min & Max \\
\hline Industrial structure rationalization (Stru1) & 156 & 1.431 & 0.789 & 0.704 & 5.234 \\
\hline Advanced industrial structure (Stru2) & 156 & 0.861 & 0.307 & 0.251 & 1.757 \\
\hline Structural characteristics of high-tech industry (Stru3) & 156 & 0.251 & 0.075 & 0.092 & 0.478 \\
\hline Production service industry structure (Stru4) & 156 & 2.266 & 0.726 & 1.381 & 5.049 \\
\hline $\begin{array}{c}\text { "Double First-class" college graduates employment mobility } \\
\text { proportion (Mobility) }\end{array}$ & 156 & 0.027 & 0.0074 & 0.0120 & 0.049 \\
\hline Urbanization rate (Urban) & 156 & 0.599 & 0.119 & 0.400 & 0.896 \\
\hline Fiscal decentralization (Fiscal) & 156 & 6.102 & 2.602 & 3.150 & 14.89 \\
\hline Open to the outside world (Open) & 156 & 971,574 & 766,618 & 4356 & 2817231 \\
\hline Investment in fixed assets (Fix) & 156 & 14,686 & 8812 & 1689 & 37,664 \\
\hline Technological innovation (Tech) & 156 & 30,545 & 44,448 & 441 & 272,616 \\
\hline Infrastructure (Infra) & 156 & 1.081 & 0.447 & 0.304 & 2.115 \\
\hline
\end{tabular}

Table 2 is the correlation coefficient matrix of the data. The regression results showed that the average value of the variance inflation factor VIF of each variable was 4.78 . Therefore, the degree of multicollinearity between the variables can be considered relatively acceptable. 
Table 2. Correlation coefficient matrix.

\begin{tabular}{|c|c|c|c|c|c|c|c|c|c|c|c|}
\hline $\begin{array}{l}\text { Variable } \\
\text { Name }\end{array}$ & 1 & 2 & 3 & 4 & 5 & 6 & 7 & 8 & 9 & 10 & 11 \\
\hline 1.Stru1 & 1 & & & & & & & & & & \\
\hline 2.Stru2 & 0.6218 * & 1 & & & & & & & & & \\
\hline 3.Stru3 & 0.2598 * & 0.4465 * & 1 & & & & & & & & \\
\hline 4.Stru4 & $0.6259 *$ & $0.7518^{*}$ & $0.3089 *$ & 1 & & & & & & & \\
\hline Mobility & 0.0740 & -0.172 & $-0.3546^{*}$ & 0.2590 * & 1 & & & & & & \\
\hline 6.Urban & 0.5171 * & $0.8682 *$ & $0.5472 *$ & $-0.2513 *$ & -0.172 & 1 & & & & & \\
\hline 7.Fiscal & $0.7269 *$ & 0.7468 * & $0.2905^{*}$ & -0.117 & -0.0961 & $0.7885^{*}$ & 1 & & & & \\
\hline 8.Open & -0.0877 & $0.3472 *$ & 0.6598 * & $-0.4511^{*}$ & $-0.2567^{*}$ & 0.5097 * & 0.159 & 1 & & & \\
\hline 9.Fix & -0.5734 * & -0.171 & $0.3996^{*}$ & -0.3171 * & $-0.2375 *$ & -0.152 & $-0.4538^{*}$ & 0.5281 * & 1 & & \\
\hline 10.Infra & 0.0971 & 0.5158 * & $0.6233^{*}$ & $-0.6042 *$ & $-0.2727^{*}$ & 0.5234 * & $0.3544 *$ & 0.5900 * & 0.2855 * & 1 & \\
\hline 11.Tech & -0.113 & $0.2818^{*}$ & $0.4768 *$ & $0.3370 *$ & $-0.5082 *$ & 0.2995 * & -0.0341 & 0.7140 * & 0.5143 * & 0.3342 * & 1 \\
\hline
\end{tabular}

Note: ${ }^{*}$ mean significant at the levels of $10 \%, 5 \%$, and $1 \%$, respectively, and the number in parentheses is the " $t$ " value of the estimated coefficient.

This article mainly studies the relationship between the employment mobility of college graduates and the industrial structure, including the relationship between the employment mobility of college graduates and the rationalization of industrial structure, advanced industrial structure, high-tech industrial structure, and the industrial structure of producer services. Among them, the focus is on the relationship between college graduates' employment mobility, the industrial structure of high-tech industries, and the industrial structure of producer services. The structural characteristics of the high-tech industry are expressed by the proportion of high-tech manufacturing in the total manufacturing output. The structural characteristics of the producer service industry are expressed by the ratio of the high-end producer service industry to the low-end producer service industry [40].

According to Figures 1 and 2, it can be seen that the high-tech industrial structure of various provinces has not changed much from 2014 to 2019. The industrial structure of the producer service industry has shown an increasing trend every year. Figure 1 shows that the provinces with a high proportion of high-tech manufacturing in total manufacturing output are Beijing, Guangdong, Jiangsu, and Chongqing. At the same time, Gansu and Guangxi have a relatively low proportion. Figure 2 shows that Beijing, Guangdong, Hebei, Jiangsu, Shanghai, Tianjin, and Zhejiang have a higher ratio of high-end producer services to low-end producer services. In contrast, Gansu, Hainan, Jiangxi, and Chongqing have a lower ratio.

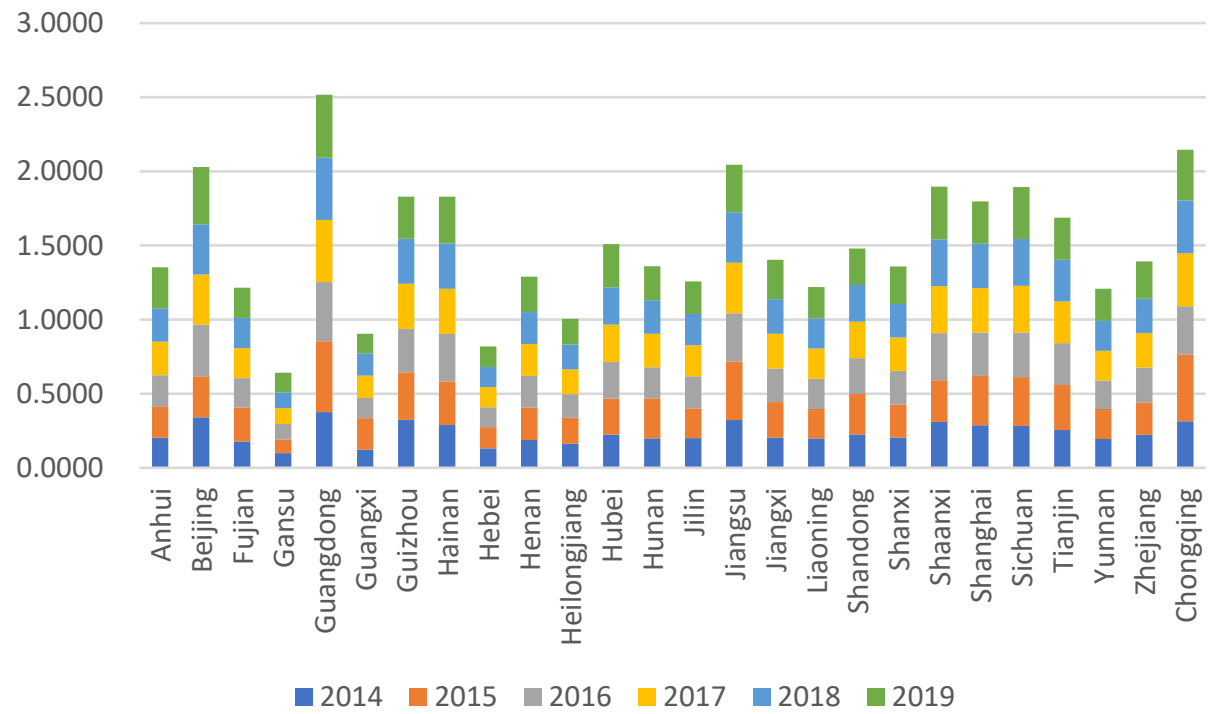

Figure 1. The characteristics of the industrial structure of high-tech manufacturing industries in various provinces from 2014 to 2019. 


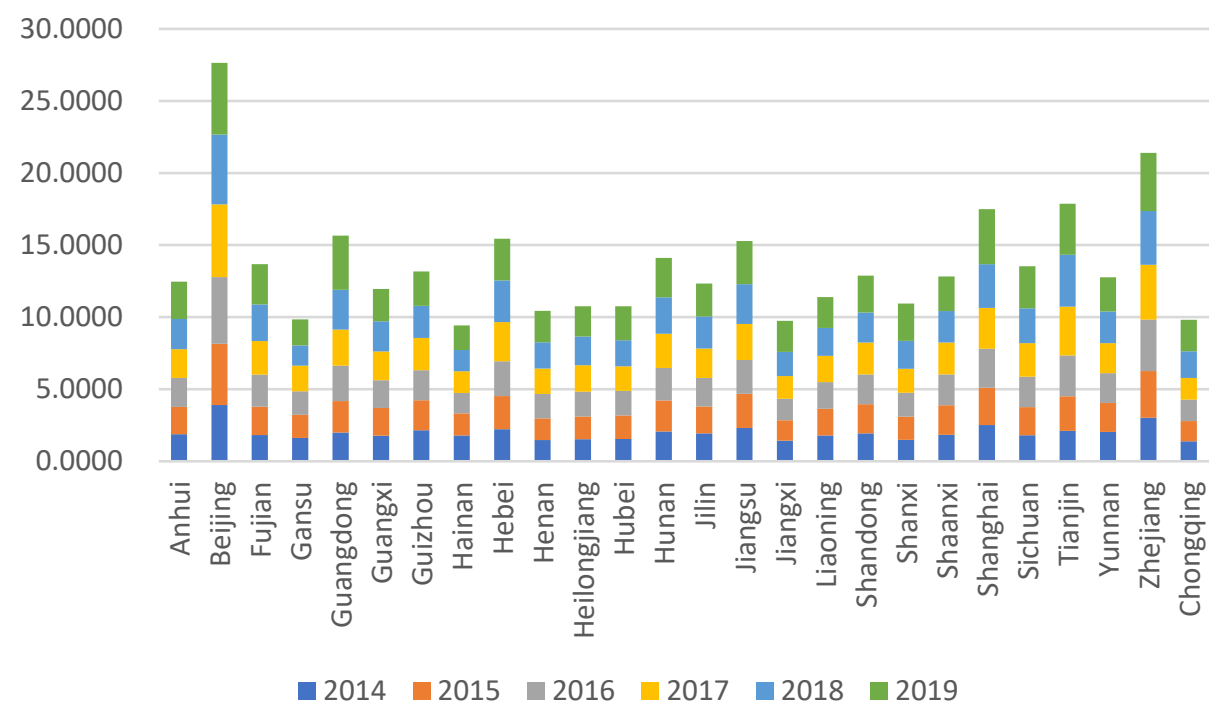

Figure 2. Industrial structure characteristics of the producer service industry in each province from 2014 to 2019.

\section{Analysis of Empirical Test Results}

\subsection{Benchmark Regression Analysis}

Table 3 shows that the coefficient of graduate flow and industrial structure rationalization is 0.9728 , significant at the $1 \%$ level. The coefficient of graduate flow and industrial structure advancement is 0.1111 , significant at the $1 \%$ level. The flow of graduates and the upgrading coefficient of the high-tech industry structure is 0.1839 , which is below the $5 \%$ level. The industrial structure upgrading coefficient of the graduate flow and the productive service industry is 0.1839 , which is significant at the $1 \%$ level. The regression results show that the influx of "Double First-class" college graduates plays a significant role in optimizing and upgrading various provinces' industrial structures.

Table 3. Regression results of the proportion of employment mobility of college graduates and the industrial structure.

\begin{tabular}{ccccc}
\hline Dependent Variable & Stru1 & Stru2 & Stru3 & Stru4 \\
\hline Mobility & $0.9728^{* * *}$ & $0.1111^{* * *}$ & $0.1839^{* * *}$ & $0.8382^{* * *}$ \\
& $(12.83)$ & $(11.42)$ & $(2.58)$ & $(9.30)$ \\
Constant & $3.8108^{* * *}$ & $2.3159^{* * *}$ & $0.7629^{* * *}$ & $3.8271^{* * *}$ \\
& $(13.81)$ & $(65.36)$ & $(2.94)$ & $(11.66)$ \\
Number of samples & 156 & 156 & 156 & 156 \\
Number of provinces & 26 & 26 & 26 & 26 \\
\hline
\end{tabular}

Note: ${ }^{* *},{ }^{* *}$ mean significant at the levels of $10 \%, 5 \%$, and $1 \%$, respectively, and the number in parentheses is the " $t$ " value of the estimated coefficient.

Table 4 shows the nationwide regression results after controlling for the variables. The industrial structure rationalization coefficient has changed from 0.9728 to 0.5953 ; the advanced industrial structure coefficient has changed from 0.1111 to 0.0507 . Moreover, the high-tech industry coefficient has changed from 0.1839 to 0.0150 , and the producer service industry coefficient has changed from 0.8382 to 0.3935 . The regression coefficients of the four explained variables all decrease, and the regression results are statistically significant positive.

This shows that, even after controlling for the control variables, the influx of college graduates is important in promoting industrial structure rationalization, advanced industrial structure, high-tech industry optimization and upgrading, and producer service industry optimization and upgrading. Among them, the promotion of industrial structure rationalization and upgrading of the high-end producer service industry structure is 
relatively strong. In contrast, promoting industrial structure upgrading and upgrading the high-tech industrial structure is relatively weak. One possible explanation is that the number of graduates from China's "Double First-class" colleges and universities is relatively large in the tertiary and producer service industries, while the number of people in high-tech industries is relatively small.

Table 4. Benchmark regression model nationwide.

\begin{tabular}{ccccc}
\hline Dependent Variable & Stru1 & Stru2 & Stru3 & Stru4 \\
\hline Mobility & $0.5953^{* * *}$ & $0.0507^{* * *}$ & $0.0150^{* *}$ & $0.3935^{* * *}$ \\
& $(6.65)$ & $(4.61)$ & $(0.15)$ & $(3.80)$ \\
Urban & $0.7807^{* * *}$ & $0.0764^{* * *}$ & 0.3131 & 0.0218 \\
& $(3.93)$ & $(3.13)$ & $(1.39)$ & $(0.09)$ \\
Fiscal & $-0.1341^{*}$ & $-0.0155^{* *}$ & 0.0431 & $-0.4615^{* * *}$ \\
& $(-1.69)$ & $(-1.59)$ & $(0.33)$ & $(-5.02)$ \\
Open & -0.0237 & -0.0030 & 0.0206 & -0.0182 \\
& $(-1.15)$ & $(-1.18)$ & $(0.93)$ & $(-0.76)$ \\
Fix & $0.0618^{*}$ & 0.0047 & -0.0254 & $0.1294^{* * *}$ \\
& $(1.69)$ & $(1.06)$ & $(-0.63)$ & $(3.06)$ \\
Infra & $0.4422^{* * *}$ & $0.0692^{* * *}$ & $0.4169 * *$ & 0.1423 \\
& $(2.77)$ & $(3.53)$ & $(2.36)$ & $(0.77)$ \\
Constant & $2.6143^{* * *}$ & $2.0445^{* * *}$ & $-5.9229 * * *$ & 0.8370 \\
& $(4.20)$ & $(26.77)$ & $(-5.74)$ & $(1.16)$ \\
Number of samples & 156 & 156 & 156 & 156 \\
Number of provinces & 26 & 26 & 26 & 26
\end{tabular}

Note: ${ }^{* * *},{ }^{* * *}$ mean significant at the levels of $10 \%, 5 \%$, and $1 \%$, respectively, and the number in parentheses is the " $t$ " value of the estimated coefficient.

Among the control variables, the regression coefficient between the urbanization rate and the rationalization of the industrial structure is 0.7807 , which is significant at the $1 \%$ level. The regression coefficient between the urbanization rate and the advanced industrial structure is 0.0764 , significant at the $1 \%$ level. This reveals that, while urbanization can improve the national industrial structure's rationalization and advancement index through human capital agglomeration, the rate of urbanization has no discernible effect on promoting the industrial upgrading of high-tech industries and producer service industries [47]. The degree of opening to the outside world has no significant impact on optimizing and upgrading the industrial structure. The allocation of foreign direct investment in China's industrial structure is currently unreasonable. Hence, only reasonable structural changes to foreign direct investment industries can enable long-term sustainable economic development [48]. The regression coefficient of fiscal decentralization and industrial structure rationalization is -0.1341 , which is significant at the level of $10 \%$. The regression coefficient of fiscal decentralization and industrial upgrading of producer services is -0.4615 , significant at the $1 \%$ level. This shows that fiscal decentralization is not conducive to upgrading the industrial structure, and fiscal decentralization has aggravated the degree of industrial structure imbalance [49].

Finally, the regression results show that the more investment there is in fixed assets in the tertiary industry and producer services, the more conducive to upgrading the industrial structure. The improvement of the industrial structure is an important manifestation of the economic quality of a country or region. In industrial structure evolution, fixed asset investment plays a role in promotion and promotion [50]. Infrastructure has a significant impact on the upgrading of the industrial structure. The more complete the infrastructure, the better the industrial structure can be optimized. The "spatial spillover effect" of infrastructure is conducive to upgrading the industrial structure [51].

\subsection{Robustness Test}

This paper employs the indicator replacement method to perform the robustness test. Replace actual FDI with the ratio of FDI to GDP, fixed asset investment with per capita fixed 
asset investment, and R\&D expenditures with the number of patent applications accepted. Table 5 shows the regression results after running the data through the fixed effects and random effects models. Table 5 shows that the regression results are consistent with the original regression model after the index replacement. This demonstrates that the data in this paper is extremely robust.

Table 5. Robustness test.

\begin{tabular}{|c|c|c|c|c|c|c|c|c|}
\hline Model & FE & FE & FE & FE & RE & RE & RE & RE \\
\hline Dependent Variable & Stru1 & Stru2 & Stru3 & Stru4 & Stru1 & Str2 & Stru3 & Stru4 \\
\hline Mobility & $\begin{array}{c}0.5613^{* * *} \\
(6.53)\end{array}$ & $\begin{array}{c}0.0562 \text { *** } \\
(5.14)\end{array}$ & $\begin{array}{c}0.0076 \text { * } \\
(0.08)\end{array}$ & $\begin{array}{c}0.4448^{* * *} \\
(4.19)\end{array}$ & $\begin{array}{c}0.5135^{* * *} \\
(6.45)\end{array}$ & $\begin{array}{c}0.0276^{* * *} \\
(3.25)\end{array}$ & $\begin{array}{c}0.0292 * \\
(0.37)\end{array}$ & $\begin{array}{c}0.1816 \text { ** } \\
(2.09)\end{array}$ \\
\hline Urban & $\begin{array}{c}0.9692^{* * *} \\
(4.95)\end{array}$ & $\begin{array}{c}0.1053^{* * *} \\
(4.23)\end{array}$ & $\begin{array}{c}0.2645 \\
(1.24)\end{array}$ & $\begin{array}{c}0.4655 * \\
(1.92)\end{array}$ & $\begin{array}{c}1.1573 * * * \\
(6.56)\end{array}$ & $\begin{array}{c}0.1730^{* * *} \\
(9.35)\end{array}$ & $\begin{array}{l}0.2836 \\
(1.63)\end{array}$ & $\begin{array}{c}0.9779 * * * \\
(5.16)\end{array}$ \\
\hline Fiscal' $^{\prime}$ & $\begin{array}{l}-0.0473 \\
(-0.40)\end{array}$ & $\begin{array}{l}-0.0036 \\
(-0.24)\end{array}$ & $\begin{array}{c}0.0260 \\
(0.20)\end{array}$ & $\begin{array}{c}-0.2770 * \\
(-1.90)\end{array}$ & $\begin{array}{c}-0.2108^{* *} \\
(-2.10)\end{array}$ & $\begin{array}{c}0.0101 \\
(1.03)\end{array}$ & $\begin{array}{c}0.0750 \\
(0.77)\end{array}$ & $\begin{array}{c}-0.1603 \\
(-1.57)\end{array}$ \\
\hline Open' & $\begin{array}{c}2.0855 \\
(1.49)\end{array}$ & $\begin{array}{c}0.1173 \\
(0.66)\end{array}$ & $\begin{array}{c}-0.4258 \\
(-0.28)\end{array}$ & $\begin{array}{c}3.6731^{* *} \\
(2.13)\end{array}$ & $\begin{array}{c}2.0011 \\
(1.35)\end{array}$ & $\begin{array}{c}0.0975 \\
(0.50)\end{array}$ & $\begin{array}{c}-0.4848 \\
(-0.32)\end{array}$ & $\begin{array}{c}3.5234 \text { * } \\
(1.85)\end{array}$ \\
\hline Fix' & $\begin{array}{l}2.1116 \\
(1.52)\end{array}$ & $\begin{array}{c}0.1202 \\
(0.68)\end{array}$ & $\begin{array}{c}-0.4362 \\
(-0.29)\end{array}$ & $\begin{array}{c}3.6864^{* *} \\
(2.14)\end{array}$ & $\begin{array}{l}2.0547 \\
(1.39)\end{array}$ & $\begin{array}{c}0.1063 \\
(0.55)\end{array}$ & $\begin{array}{l}-0.4944 \\
(-0.33)\end{array}$ & $\begin{array}{c}3.5666^{*} \\
(1.88)\end{array}$ \\
\hline Infra & $\begin{array}{l}1.6522 \\
(1.19)\end{array}$ & $\begin{array}{c}0.0440 \\
(0.25)\end{array}$ & $\begin{array}{c}0.8027 \\
(0.53)\end{array}$ & $\begin{array}{c}-3.3821 \\
(-1.97)\end{array}$ & $\begin{array}{l}1.9085 \\
(1.29)\end{array}$ & $\begin{array}{c}0.0734 \\
(0.38)\end{array}$ & $\begin{array}{c}0.8755 \\
(0.58)\end{array}$ & $\begin{array}{c}3.3650 * \\
(1.78)\end{array}$ \\
\hline Constant & $\begin{array}{c}3.0566^{* * *} \\
(8.99)\end{array}$ & $\begin{array}{c}2.2052^{* * *} \\
(51.04)\end{array}$ & $\begin{array}{c}-0.9921^{* * *} \\
(-2.68)\end{array}$ & $\begin{array}{c}3.5772 * * * \\
(8.51)\end{array}$ & $\begin{array}{c}2.9661^{* * *} \\
(9.30)\end{array}$ & $\begin{array}{c}2.1276^{* * *} \\
(60.69)\end{array}$ & $\begin{array}{c}-1.0751^{* * *} \\
(-3.40)\end{array}$ & $\begin{array}{c}2.8144^{* * *} \\
(7.91)\end{array}$ \\
\hline Number of samples & 156 & 156 & 156 & 156 & 156 & 156 & 156 & 156 \\
\hline Number of provinces & 26 & 26 & 26 & 26 & 26 & 26 & 26 & 26 \\
\hline
\end{tabular}

Note: ${ }^{*}{ }^{* *},{ }^{* * *}$ mean significant at the levels of $10 \%, 5 \%$, and $1 \%$, respectively, and the number in parentheses is the " $t$ " value of the estimated coefficient.

Panel data models are prone to inter-group heteroscedasticity and intra-group sequence correlation, which cause ordinary least squares estimation to fail. A comprehensive FGLS is typically used to perform regression analysis on the model to solve the problem of intra-group sequence correlation and inter-group heteroscedasticity. As can be seen from Table 6, the regression results of the FGLS model are basically consistent with the regression results of the above models. Therefore, the model has good robustness to different measurement methods. It shows that the model is robust to different measurement methods.

Table 6. Robustness test (FGLS).

\begin{tabular}{ccccc}
\hline Model & $\mathbf{( 1 )}$ & $\mathbf{( 2 )}$ & $\mathbf{( 3 )}$ & $\mathbf{( 4 )}$ \\
\hline Dependent Variable & Stru1 & Stru2 & Stru3 & Stru4 \\
\hline Mobility & $0.3818^{* * *}$ & $0.0129^{* *}$ & $0.1224^{*}$ & $0.3649^{* *}$ \\
& $(3.27)$ & $(0.04)$ & $(1.35)$ & $(2.15)$ \\
Urban & $0.8294^{* * *}$ & $0.2546^{* *}$ & $0.6324^{* * *}$ & $1.1390^{* * *}$ \\
& $(4.37)$ & $(0.33)$ & $(4.98)$ & $(4.48)$ \\
Fiscal & $0.3379^{* * *}$ & -0.2085 & $0.2310^{* * *}$ & $-0.3121^{* *}$ \\
& $(3.66)$ & $(-0.85)$ & $(3.04)$ & $(-2.38)$ \\
Open & 0.0048 & $-0.0775^{* *}$ & 0.0158 & 0.0159 \\
& $(0.26)$ & $(-1.32)$ & $(1.48)$ & $(0.61)$ \\
Fix & 0.0758 & 0.3790 & 0.0557 & $0.0618^{*}$ \\
& $(1.32)$ & $(1.55)$ & $(1.44)$ & $(1.57)$ \\
Infra & 0.0561 & -0.3787 & $0.8975 * * *$ & $0.1406^{* *}$ \\
& $(0.48)$ & $(-1.06)$ & $(5.05)$ & $(2.45)$ \\
Constant & $2.2312^{* * *}$ & 5.1237 & 1.3691 *** & $2.8204^{* * *}$ \\
& $(3.68)$ & $(1.36)$ & $(3.90)$ & $(3.91)$ \\
Number of samples & 156 & 156 & 156 & 156 \\
Number of provinces & 26 & 26 & 26 & 26 \\
\hline
\end{tabular}

Note: ${ }^{*}, * *, * * *$ mean significant at the levels of $10 \%, 5 \%$, and $1 \%$, respectively, and the number in parentheses is the " $t$ " value of the estimated coefficient. 
4.3. Employment Mobility of "Double First-Class" College Graduates Influences the Technological Innovation Effect Test of Industrial Structure Upgrading

According to Table 7, the regression coefficient of the proportion of total employment mobility of college graduates to total employment and technological innovation is 0.9091, which is significant at the $1 \%$ level, based on Model (1). For every unit increase in the proportion of college graduates' total employment mobility to total employment, technological innovation will increase by 0.9091 units. The influx of college graduates has a significant role in promoting technological innovation. In model (2), graduate mobility and technological innovation regression coefficients are significantly positive.

Table 7. "Double First-class" college graduates employment mobility affects the technological innovation effect test of industrial structure upgrading.

\begin{tabular}{cccccc}
\hline Model & $\mathbf{( 1 )}$ & $\mathbf{( 2 )}$ & $\mathbf{( 3 )}$ & $\mathbf{( 4 )}$ & $\mathbf{( 5 )}$ \\
\hline Dependent Variable & Tech & Stru1 & Stru2 & Stru3 & Stru4 \\
\hline Mobility & $0.9091^{* * *}$ & $0.5953^{* * *}$ & $0.0507^{* * *}$ & $-0.8061^{* * *}$ & $0.3935^{* * *}$ \\
& $(4.66)$ & $(6.65)$ & $(4.61)$ & $(-3.73)$ & $(3.80)$ \\
Urban & $1.0768^{* *}$ & $0.7807^{* * *}$ & $0.0764^{* * *}$ & 0.3607 & 0.0218 \\
& $(2.34)$ & $(3.93)$ & $(3.13)$ & $(0.75)$ & $(0.09)$ \\
Fiscal & $-0.5660^{* * *}$ & $-0.1341^{*}$ & -0.0155 & $0.4965^{* *}$ & $-0.4615^{* * *}$ \\
& $(-3.13)$ & $(-1.69)$ & $(-1.59)$ & $(2.59)$ & $(-5.02)$ \\
Open & $0.0799^{*}$ & -0.0237 & -0.0030 & -0.0616 & -0.0182 \\
& $(1.66)$ & $(-1.15)$ & $(-1.18)$ & $(-1.24)$ & $(-0.76)$ \\
Fix & $0.1655^{*}$ & $0.0618^{*}$ & 0.0047 & 0.0992 & $0.1294^{* * *}$ \\
& $(1.94)$ & $(1.69)$ & $(1.06)$ & $(1.12)$ & $(3.06)$ \\
Infra & 0.6068 & $0.4422^{* * *}$ & $0.0692^{* * *}$ & $0.6510 *$ & 0.1423 \\
& $(1.62)$ & $(2.77)$ & $(3.53)$ & $(1.69)$ & $(0.77)$ \\
Tech & & $0.0222^{* *}$ & $0.0121^{* *}$ & $-0.0246^{*}$ & $0.1272^{* * *}$ \\
& $(0.58)$ & $(2.59)$ & $(-0.27)$ & $(2.90)$ \\
Constant & $11.8426^{* * *}$ & $2.6143^{* * *}$ & $2.0445^{* * *}$ & $-5.6314^{* * *}$ & 0.8370 \\
& $(11.67)$ & $(4.20)$ & $(26.77)$ & $(-3.75)$ & $(1.16)$ \\
Number of samples & 156 & 156 & 156 & 156 & 156 \\
Number of provinces & 26 & 26 & 26 & 26 & 26 \\
\hline
\end{tabular}

Note: ${ }^{*},{ }^{* *},{ }^{* * *}$ mean significant at the levels of $10 \%, 5 \%$, and $1 \%$, respectively, and the number in parentheses is the " $t$ " value of the estimated coefficient.

This demonstrates that college graduates positively impact industrial structure rationalization by influencing technological innovation. Similarly, in models (3) and (5), graduate mobility and technological innovation regression coefficients are significantly positive. By influencing technological innovation, college graduates positively impact the advancement of the industrial structure and the optimization and upgrading of the industrial structure of the producer service industry.

In models (3) and (5), graduate mobility and technological innovation regression coefficients are significantly negative. This shows that the higher the proportion of graduates from "Double First-class" colleges and universities, the higher the proportion of high-tech industrial structure optimization and upgrading. High-end human capital has a significant positive effect and spillover effect on the innovation of high-tech industries. Low-end human capital generally has no significant effect and may even have a certain adverse effect and spillover effect [49].

As a result, the above findings could be explained by the fact that there are still too few mid-to-high-end talents for "Double First-class" college graduates or that high-end talent lacks mobility in the high-tech industry. Even though "Double First-class" college graduates have graduated from some of China's best universities, new graduates are like a blank sheet of paper, lacking relevant work experience and competence in high-tech industries. Initially, they could only work in industries with a low level of technical content. In the future, we can continue to study the migration of relevant personnel to determine whether college graduates enter the high-tech industry. 
High-tech manufacturing companies need many engineering technical R\&D personnel, but companies often cannot recruit suitable talents. At present, many colleges and universities do not offer majors related to high-tech manufacturing. Even if some schools offer related courses, they are just textbook teaching and lack practical operations. The students trained do not match the talents required by the high-tech manufacturing market, causing many college graduates to face employment difficulties. It is difficult for students to quickly enter the field of high-tech manufacturing to carry out technological research and development. The overall quality of employees in my country's manufacturing industry is not high. The junior high school education level and below is the main body of employees in my country's manufacturing industry. In state-owned enterprises, it has become a common phenomenon that the educational background and quality of technical jobs are low.

It can be seen from Table 8 that people engaged in high-tech industries are not necessarily the best college graduates. The threshold for engaging in junior technicians is relatively low. An associate degree and one year of work experience can often enter the industry. The threshold for engaging in senior technical personnel is relatively high. It requires a master's degree or above or long-term work experience. Most fresh graduates have a bachelor's degree, and there are relatively few graduates with master's and doctoral degrees. They often lack work experience in related industries. Therefore, many graduates can only start as junior technicians. Those engaged in the top high-tech industries are often experienced personnel, and most of them are not well-educated. Only a small number of Ph.D. graduates can enter key sectors of this high-tech industry in a short time. Therefore, most of these students who graduated from "Double First-class" universities do not qualify to engage in high-tech industries. There is a mismatch between the employment needs of "Double First-class" college graduates and the jobs provided by high-tech industries.

Table 8. National Vocational Technical Skills Standard (Intelligent manufacturing engineering technicians).

\begin{tabular}{|c|c|c|}
\hline Elementary & Intermediate & Senior \\
\hline 1. Obtain the title of technician. & $\begin{array}{l}\text { 1. After obtaining the title of assistant } \\
\text { engineer, he has been engaged in } \\
\text { professional technical work for } 2 \text { years. }\end{array}$ & $\begin{array}{l}\text { 1. After obtaining the title of engineer, } \\
\text { have been engaged in professional } \\
\text { technical work for } 3 \text { years. }\end{array}$ \\
\hline $\begin{array}{l}\text { 2. Possess a bachelor's degree or above in } \\
\text { relevant majors (including fresh } \\
\text { graduates currently studying). }\end{array}$ & $\begin{array}{l}\text { 2. Possess a university degree, or a } \\
\text { bachelor's degree, or a college degree, } \\
\text { after obtaining a junior professional } \\
\text { technical level, and have been engaged in } \\
\text { this vocational technical work for } 3 \text { years. }\end{array}$ & $\begin{array}{l}\text { 2. Possess a master's degree, or a second } \\
\text { bachelor's degree, or a bachelor's degree, } \\
\text { or a bachelor's degree, after obtaining an } \\
\text { intermediate professional and technical } \\
\text { level, and have been engaged in this } \\
\text { vocational and technical work for } 4 \text { years. }\end{array}$ \\
\hline $\begin{array}{l}\text { 3. Have a college degree in related majors } \\
\text { and have been engaged in this vocational } \\
\text { and technical work for one year. }\end{array}$ & $\begin{array}{l}\text { 3. Having a master's degree or a second } \\
\text { bachelor's degree, and after obtaining a } \\
\text { junior professional technical level, have } \\
\text { been engaged in this vocational and } \\
\text { technical work for one year. }\end{array}$ & $\begin{array}{l}\text { 3. Having a doctorate degree and } \\
\text { obtaining an intermediate professional } \\
\text { and technical level, have been engaged in } \\
\text { this vocational and technical work for at } \\
\text { least } 1 \text { year. }\end{array}$ \\
\hline \multirow[t]{2}{*}{$\begin{array}{l}\text { 4. Graduates of technical colleges and } \\
\text { universities shall declare in accordance } \\
\text { with relevant national regulations. }\end{array}$} & $\begin{array}{l}\text { 4. Possess a doctorate degree in related } \\
\text { disciplines. }\end{array}$ & $\begin{array}{l}\text { 4. Graduates of technical colleges and } \\
\text { universities shall declare in accordance } \\
\text { with relevant national regulations. }\end{array}$ \\
\hline & $\begin{array}{l}\text { 5. Graduates of technical colleges and } \\
\text { universities shall declare in accordance } \\
\text { with relevant national regulations. }\end{array}$ & \\
\hline
\end{tabular}

\section{Regional Heterogeneity Analysis}

According to Table 9, the regression coefficient between the rationalization of the industrial structure and the mobility of graduates in the eastern region is 0.8297 , which is significant at the $1 \%$ level. The regression coefficient between the rationalization of the 
industrial structure in the central region and the mobility of graduates is 0.7250 , which is significant at the $1 \%$ level. The regression coefficient between the rationalization of the industrial structure in the western region and the mobility of graduates is 0.3448 , which is significant at the $5 \%$ level. The regression results reveal that the greater the total proportion of college and university graduates in the three regions, the greater the degree of rationalization of the industrial structure.

Table 9. Regression model for rationalization of the industrial structure by region.

\begin{tabular}{cccc}
\hline Dependent Variable & Stru1 & Stru1 & Stru1 \\
\hline Regional Variables & Eastern Region & Central Region & Western Region \\
\hline Mobility & $0.8297^{* * *}$ & $0.7250^{* * *}$ & $0.3448^{*}$ \\
Urban & $(0.1045)$ & $(0.2047)$ & $(0.1984)$ \\
& 0.0563 & 0.9599 & $0.8888^{* * *}$ \\
Fiscal & $(0.3370)$ & $(0.6091)$ & $(0.2509)$ \\
& -0.0752 & -0.0894 & -0.1434 \\
Open & $(0.0973)$ & $(0.1843)$ & $(0.1571)$ \\
& -0.0435 & 0.0053 & -0.0284 \\
Fix & $(0.0276)$ & $(0.1233)$ & $(0.0270)$ \\
& $0.1204^{* *}$ & 0.1543 & -0.0227 \\
Infra & $(0.0453)$ & $(0.1030)$ & $(0.0830)$ \\
& $0.5119^{* * *}$ & 0.3595 & $0.6321 *$ \\
Constant & $(0.1875)$ & $(0.3648)$ & $(0.3559)$ \\
& $3.0934^{* * *}$ & 1.8426 & $3.0621^{* *}$ \\
Number of samples & $(0.5048)$ & $(1.5300)$ & $(1.2833)$ \\
Number of provinces & 66 & 48 & 42 \\
\hline
\end{tabular}

Note: ${ }^{*}, * *, * *$ mean significant at the levels of $10 \%, 5 \%$, and $1 \%$, respectively, and the number in parentheses is the " $t$ " value of the estimated coefficient.

The regression coefficient between the rationalization of the industrial structure in the central region and the mobility of graduates is 0.7250 , which is significant at the $1 \%$ level. The regression coefficient between the rationalization of the industrial structure in the western region and the mobility of graduates is 0.3448 , which is significant at the $5 \%$ level. The regression results show that the greater the total proportion of graduates from colleges and universities in the three regions, the higher the degree of rationalization of the industrial structure.

Table 9 shows that the western region's urbanization rate and industrial structure rationalization coefficient are 0.8888 , with a significant level of $1 \%$. It shows that the higher the urbanization rate in the western region, the more reasonable the industrial structure. The impact of fiscal decentralization on the rationalization of industrial structure is negative and insignificant. Fiscal decentralization is not conducive to the rationalization of the industrial structure. The influence of opening to the outside world on the rationalization of the industrial structure is not obvious and negative on the whole, which shows that opening to the outside world inhibits the rationalization of the industrial structure, which is consistent with the research results of scholars such as Sun Jin [49]. The impact of fixed asset investment on the rationalization of the industrial structure in the eastern region is 0.1204 at a significant level of $5 \%$. The impact on upgrading the industrial structure of the producer service industry is negative. The impact of infrastructure on the rationalization of the industrial structure in the eastern region is 0.5119 at a significant level of $1 \%$. The impact on the rationalization of the industrial structure in the western region at a significant level of $10 \%$ is 0.6321 , and the impact on the central region is not significant.

It can be seen from Table 10 that the regression coefficient of graduate mobility and advanced industrial structure in the eastern region is 0.0873 , which is significant at the $1 \%$ level. The regression coefficient of graduate mobility and advanced industrial structure in the western region is 0.0702 , significant at the $1 \%$ level. This shows that the higher the 
proportion of the total number of college graduates after the immigrants are employed, the more they can promote the industrial development of the eastern and western regions.

Table 10. Advanced regression model of the industrial structure by region.

\begin{tabular}{cccc}
\hline Dependent Variable & Stru2 & Stru2 & Stru2 \\
\hline Regional Variables & Eastern Region & Central Region & Western Region \\
\hline Mobility & $0.0873^{* * *}$ & 0.0442 & $0.0702^{* * *}$ \\
Urban & $(0.0089)$ & $(0.0286)$ & $(0.0242)$ \\
& 0.0156 & $0.1769 * *$ & $0.0930^{* * *}$ \\
Fiscal & $(0.0287)$ & $(0.0852)$ & $(0.0306)$ \\
& -0.0108 & -0.0049 & $-0.0599 * * *$ \\
Open & $(0.0083)$ & $(0.0258)$ & $(0.0192)$ \\
& -0.0017 & 0.0210 & $-0.0061^{*}$ \\
Fix & $(0.0024)$ & $(0.0172)$ & $(0.0033)$ \\
& $0.0098^{* *}$ & -0.0023 & -0.0109 \\
Infra & $(0.0039)$ & $(0.0144)$ & $(0.0101)$ \\
& $0.0798^{* * *}$ & 0.0621 & 0.0161 \\
Constant & $(0.0160)$ & $(0.0510)$ & $(0.0435)$ \\
& $2.2110^{* * *}$ & $1.9041^{* * *}$ & $2.4852^{* * *}$ \\
Number of samples & $(0.0431)$ & $(0.2139)$ & $(0.1567)$ \\
Number of provinces & 66 & 48 & 42 \\
\end{tabular}

Note: ${ }^{*}{ }^{* *},{ }^{* * *}$ mean significant at the levels of $10 \%, 5 \%$, and $1 \%$, respectively, and the number in parentheses is the " $t$ " value of the estimated coefficient.

The regression coefficient between the urbanization rate and the advanced industrial structure in the central region is 0.1769 , which is significant at the $5 \%$ level. The regression coefficient between the urbanization rate and the advanced industrial structure in the western region is 0.0930 , significant at the $1 \%$ level. The urbanization rate promotes upgrading the high-tech industrial structure in the central and western regions. Fiscal decentralization is still not conducive to the upgrading of the industrial structure.

According to the regression results in Table 11, the regression coefficient between graduate mobility and the optimization of the high-tech industry structure in the eastern region is 0.0789 , significant at the $1 \%$ level. The regression coefficient between the mobility of graduates and the advanced structure of high-tech industries in the western region is 0.0602 , significant at the level of $5 \%$. Therefore, the inflow of employment for college graduates can promote the optimization and upgrading of the high-tech industrial structure in the eastern and western regions.

The regression coefficient between the urbanization rate and the optimization of the high-tech industry structure in the central region is 0.1769 , which is significant at the $5 \%$ level. The regression coefficient between the urbanization rate and the advanced structure of the high-tech industry in the western region is 0.0930 , which is significant at the $1 \%$ level. The regression coefficients of fiscal decentralization and high-tech industrial structure optimization are negative on the whole, and fiscal decentralization inhibits the optimization and upgrading of high-tech industrial structures. The regression coefficients of opening to the outside world and optimization of the high-tech industry structure are negative.

According to Table 12, it can be seen that the regression coefficient between graduate mobility and the industrial structure of the producer service industry is 0.7972 , which is significant at the $1 \%$ level. The regression coefficient between graduate mobility and the advanced structure of high-tech industries in the central region is 0.3632 , which is significant at the level of $5 \%$. The regression coefficient between the mobility of graduates and the advanced structure of high-tech industries in the western region is -0.0525 . 
Table 11. Regression model of the high-tech industry by region.

\begin{tabular}{cccc}
\hline Dependent Variable & Stru3 & Stru3 & Stru3 \\
\hline Regional Variables & Eastern Region & Central Region & Western Region \\
\hline Mobility & $0.0873^{* * *}$ & 0.0442 & $0.0702 * * *$ \\
Urban & $(0.0089)$ & $(0.0286)$ & $(0.0242)$ \\
& 0.0156 & $0.1769^{* *}$ & $0.0930 * * *$ \\
Fiscal & $(0.0287)$ & $(0.0852)$ & $(0.0306)$ \\
& -0.0108 & -0.0049 & $-0.0599 * * *$ \\
Open & $(0.0083)$ & $(0.0258)$ & $(0.0192)$ \\
& -0.0017 & 0.0210 & $-0.0061^{*}$ \\
Fix & $(0.0024)$ & $(0.0172)$ & $(0.0033)$ \\
& $0.0098^{* *}$ & -0.0023 & -0.0109 \\
Infra & $(0.0039)$ & $(0.0144)$ & $(0.0101)$ \\
& $0.0798^{* * *}$ & 0.0621 & 0.0161 \\
Constant & $(0.0160)$ & $(0.0510)$ & $(0.0435)$ \\
& $2.2110^{* * *}$ & $1.9041 * * *$ & $2.4852 * * *$ \\
Number of samples & $(0.0431)$ & $(0.2139)$ & $(0.1567)$ \\
Number of provinces & 66 & 48 & 42 \\
\end{tabular}

Note: ${ }^{* * *},{ }^{* * *}$ mean significant at the levels of $10 \%, 5 \%$, and $1 \%$, respectively, and the number in parentheses is the " $t$ " value of the estimated coefficient.

Table 12. Regression model of the producer service industry by region.

\begin{tabular}{cccc}
\hline Dependent Variable & Stru4 & Stru4 & Stru4 \\
\hline Regional Variables & Eastern Region & Central Region & Western Region \\
\hline Mobility & $0.7972^{* * *}$ & $0.3632^{* *}$ & -0.0525 \\
Urban & $(0.1673)$ & $(0.1404)$ & $(0.2052)$ \\
Fiscal & 0.6741 & $0.8184^{*}$ & -0.2548 \\
\hline Open & $(0.5394)$ & $(0.4177)$ & $(0.2593)$ \\
& $-0.5493^{* * *}$ & $-0.7029^{* * *}$ & $-0.3687^{* *}$ \\
Fix & $(0.1557)$ & $(0.1264)$ & $(0.1625)$ \\
& -0.0410 & -0.1057 & -0.0014 \\
Infra & $(0.0441)$ & $(0.0846)$ & $0.0280)$ \\
& $0.3262^{* * *}$ & 0.0211 & $0.1655^{*}$ \\
Constant & $(0.0725)$ & $(0.0706)$ & $0.0858)$ \\
& -0.3105 & $0.5535^{* *}$ & $(0529 * * * 3680)$ \\
Number of samples & $(0.3002)$ & $(0.2502)$ & -0.2590 \\
Number of provinces & $2.8327^{* * *}$ & $4.7531^{* * *}$ & $(1.3268)$ \\
\end{tabular}

Note: ${ }^{*}, * *, * * *$ mean significant at the levels of $10 \%, 5 \%$, and $1 \%$, respectively, and the number in parentheses is the " $t$ " value of the estimated coefficient.

This shows that the greater the number of college graduates flowing into the eastern and central regions, the more conducive to optimizing and upgrading the producer service industry's industrial structure. However, the greater the number of college graduates who enter the western region, the more difficult it is to optimize and upgrade the industrial structure of the western region's producer service industry. The high-end producer service industry is scarce due to the western region's backward economic development and poor conditions in all aspects. Most college graduates are engaged in low-end producer services, so the influx of college graduates has inhibited the optimization and upgrading of the industrial structure of producer services.

The rate of urbanization is important in promoting the industrial structure of the producer service industry in the central region. The regression coefficients of fiscal decentralization and the industrial structure of the producer service industry are all significantly negative in the three major regions, indicating that fiscal decentralization inhibits the opti- 
mization and upgrading of the producer service industry's industrial structure. Opening up to the outside world has a restraining effect as well. Infrastructure can help improve and upgrade producer services' industrial structure in the central and western regions.

\section{Conclusions and Policy Implications}

Based on data on the employment mobility of "Double First-class" college graduates from 2014 to 2019, this paper develops a regression model of the employment mobility of "Double First-class" college graduates influencing industrial structure upgrading. The main conclusions are as follows:

First, from a national perspective, the mobility of graduates from "Double First-class" colleges and universities has a positive effect on upgrading the industrial structure of various provinces. The difference is that the mobility of "Double First-class" college graduates has a greater effect on the rationalization of the industrial structure and the upgrading of the industrial structure of high-end producer services but has a weak effect on the advancement of the industrial structure and the upgrading of the high-tech industrial structure.

Second, the greater the number of "Double First-class" college graduates flowing into each province, the more conducive to the technological innovation effect of rationalizing the industrial structure, upgrading the industrial structure, and optimizing and upgrading the industrial structure of the producer service industry. On the contrary, the greater the number of "Double First-class" college graduates flowing into each province is not conducive to the technological innovation effect of optimizing and upgrading the high-tech industrial structure.

Third, from a regional perspective, the higher the proportion of the total number of graduates from "Double First-class" colleges and universities after employment mobilities, the higher the degree of rationalization of the industrial structure in the three major regions. The higher the proportion of the total number of graduates from "Double First-class" colleges and universities after employment mobilities, the higher the degree of advanced industrialization in the eastern and western regions, and the more reasonable the structure of the high-tech industry. The higher the proportion of the total number of graduates from "Double First-class" colleges and universities after employment mobilities, the higher the degree of optimization and upgrading of the industrial structure of the producer service industry in the eastern and central regions.

This paper draws the above conclusion based on the theoretical basis that human capital can drive industrial structure transformation and that industrial structure is endogenous to factor endowments. Based on this, the following policy recommendations are provided:

First, from an industrial policy perspective, with the gradual deepening of the industrial structure, the formulation of industrial policies cannot be separated from the human capital foundation; otherwise, it will be difficult to achieve substantive results. The upgrading of the industrial structure is due to technological progress, changes in product demand, and intensified market competition. Since these factors themselves are constantly changing, industrial policies should also be adjusted in due course. China's regional economic development is uneven, and different regions should adopt different industrial policies.

Second, from the perspective of human capital policies, it is necessary to increase national human capital investment, especially high-level human capital investment, to meet the needs of industrial structure optimization and upgrading. Colleges and universities should pay attention to the cultivation of talents, increase the proportion of high-end talents in "Double First-class" colleges and universities, strengthen the transformation of scientific and technological achievements. At the same time, it is necessary to strengthen the construction of factor markets and promote the mobility of labor and other production factors between industries, departments, and regions. The free mobility of production factors can increase factors' marginal productivity, optimize resource allocation, promote economic growth, and alleviate structural unemployment.

This paper examines the industrial structure upgrading effect of "Double First-class" college graduates using relevant panel data from each province from 2014 to 2019. Due 
to the scarcity of data released by relevant colleges and universities, this article can only reflect the situation from 2014 to 2019 and draw preliminary conclusions, laying the groundwork for further and more in-depth research. In the future, we can continue to research academic qualifications subdivisions, such as undergraduates and postgraduates, to compare and analyze which types of talents have the most obvious driving effect on the industrial structure.

Author Contributions: Conceptualization, Y.Z.; Data Curation, Y.Z.; Methodology, F.H.; Software, Y.Z.; Writing-Original Draft, Y.Z. Supervision, Y.F. All authors have read and agreed to the published version of the manuscript.

Funding: This research is one of the results of the top-level Design for Comprehensively Improving the Innovation ability of universities a major strategic research bidding project of the Ministry of Education (2015KJW02).

Institutional Review Board Statement: Not applicable.

Informed Consent Statement: Not applicable.

Data Availability Statement: The datasets used during the current study are available from the Ministry of Education of the People's Republic of China (http:/ /www.moe.gov.cn/). The datasets generated and analyzed during the current study are available from the corresponding author on reasonable request.

Conflicts of Interest: The authors declare no conflict of interest.

\section{References}

1. Yuan, L.M. Adjusting Industry Structure to Adapt to Economy Development Change. J. Wuhan Inst. Shipbuild. Technol. 2009, 8, $51-55$.

2. Zhang, Z.R.; Wei, X.M. An International Comparison of Urbanization with Consideration of Industrial Structures Based on Data from 38 Countries and Regions. J. Beijing Technol. Bus. Univ. (Soc. Sci.) 2015, 30, 18-27.

3. Hausmann, R.; Hwang, J.; Rodrik, D. What you export matters. J. Econ. Growth 2007, 12, 1-25. [CrossRef]

4. Jin, W.D. The Dynamic Matching Effect of Human Capital and Industrial Structure Transformation-A Review of Employment, Growth and Income Distribution. Econ. Rev. 2010, 5, 137-142.

5. Silva, S.M.D.; Silva, A.M.; Cortés-González, P.; Brazienė, R. Learning to Leave and to Return: Mobility, Place, and Sense of Belonging amongst Young People Growing up in Border and Rural Regions of Mainland Portugal. Sustainability 2021, 13, 9432. [CrossRef]

6. Pan, J. The connotation and action framework of "Double First-class" construction. Jiangsu High. Educ. 2016, 5, 24-32.

7. Yue, C.J.; Li, X. An Empirical Study on Trans-Provincial Migration of Graduates in China. Educ. Econ. 2016, 4, 11-20.

8. Zhong, Q.M.; Wen, D.M. Regional imbalance in employment of college graduates and its countermeasures. Seeking 2007, 3, 117-119.

9. Zeng, G.; Hu, Y.; Wu, W.; Mensah, I.K. Employment Flow of College Graduates in China: City Preference and Group Difference. Sage Open 2021, 11, 46-54.

10. Venhorst, V.A. Graduate migration and regional familiarity. Tijdschr. Voor Econ. Soc. Geogr. 2013, 104, 109-119. [CrossRef]

11. Abreu, M.; Faggian, A.; McCann, P. Migration and inter-industry mobility of UK graduates. J. Econ. Geogr. 2015, 15, 353-385. [CrossRef]

12. Faggian, A.; Comunian, R.; Li, Q.C. Interregional migration of human creative capital: The case of "Bohemian graduates". Geoforum 2014, 55, 33-42. [CrossRef]

13. Haapanen, M.; Tervo, H. Migration of the highly educated: Evidence from residence spells of university graduates. J. Reg. Sci. 2012, 52, 587-605. [CrossRef]

14. Winters, J.V. Do earnings by college major affect graduate migration? Ann. Reg. Sci. 2017, 59, 629-649. [CrossRef]

15. Byuraeva, Y.G. Post-educational Migration of University Graduates: Trajectories, Factors, Intentions. ECO $2020,7,147-167$.

16. Rehak, S.; Eriksson, R. Migration of university graduates and structural aspects of regional higher education. Eur. Plan. Stud. 2020, 28, 1941-1959. [CrossRef]

17. Kaiser, U.; Kongsted, H.C.; Ronde, T. Does the mobility of R\&D labor increase innovation? J. Econ. Behav. Organ. 2015, 110, 91-105.

18. Faggian, A.; McCann, P. Human capital, graduate migration and innovation in British regions. Camb. J. Econ. 2009, 33, 317-333. [CrossRef]

19. Faggian, A.; McCann, P.; Sheppard, S. Some evidence that women are more mobile than men: Gender differences in UK graduate migration behavior. J. Reg. Sci. 2007, 47, 517-539. [CrossRef] 
20. Faggian, A.; McCann, P.; Sheppard, S. Human capital, higher migration: An analysis students education and graduate of Scottish and Welsh students. Urban Stud. 2007, 44, 2511-2528. [CrossRef]

21. Antosik, L.; Ivashina, N. Factors and Routes of Interregional Migration of University Graduates in Russia. Appl. Econom. 2021, 2, 107-125. [CrossRef]

22. Crescenzi, R.; Holman, N.; Orru', E. Why do they return? Beyond the economic drivers of graduate return migration. Ann. Reg. Sci. 2017, 59, 603-627. [CrossRef]

23. Tamura, R. Human capital and the switch from agriculture to industry. J. Econ. Dyn. Control 2002, 16, 67-78. [CrossRef]

24. Storper, M.; Scott, A.J. Rethinking human capital, creativity. J. Econ. Geogr. 2009, 9, 147-167. [CrossRef]

25. Gennaioli, N.; La Porta, R.; Lopez-de-Silanes, F.; Shleifer, A. Human Capital and Regional Development. Q. J. Econ. 2013, 128, 105-164. [CrossRef]

26. Florida, R.; Mellander, C.; Stolarick, K. Human capital, the creative class and tolerance. J. Econ. Geogr. 2007, 8, 615-649. [CrossRef]

27. Romer, P.M. Endogenous Technological Change. J. Political Econ. 1990, 98, 80-94. [CrossRef]

28. Acemoglu, D. Patterns of Skill Premia; NBER Working Papers: Cambridge, MA, USA, 1999; pp. 1-34.

29. Romalis, J. Factor Proportions and the Structure of Commodity Trade. Am. Econ. Rev. 2004, 94, 67-97. [CrossRef]

30. Ramos, R.; Suriñach, J.; Artís, M. Regional Economic Growth and Human Capital: The Role of Overeducation; Institute for the Study of Labor (IZA): Barcelona, Spain, 2009; pp. 45-66.

31. Lin, J.Y. New Structural Economics: Reconstructing the Framework of Development Economics. China Econ. Q. 2011, $10,3-35$.

32. Gereffi, G. International trade and industrial upgrading in the apparel commodity chain. J. Int. Econ. 1999, 48, 37-70. [CrossRef]

33. Wang, Y.F.; Bai, X.; Cheng, Y.J. Endowment Structure, Technological Innovation and Industrial Structure Upgrading. In Proceedings of the Portland International Conference on Management of Engineering and Technology (PICMET), Portland, OR, USA, 9-13 July 2017; pp. 23-43.

34. Ju, J.D.; Lin, J.Y.; Wang, Y. Endowment structures, industrial dynamics, and economic growth. J. Monet. Econ. 2015, 76, 244-263. [CrossRef]

35. Lin, J.Y.; Sun, X.F.; Jiang, Y. Endowment, industrial structure, and appropriate financial structure: A new structural economics perspective. J. Econ. Policy Reform 2013, 16, 109-122. [CrossRef]

36. Amin, M.; Mattoo, A. Human capital and the changing structure of the Indian economy. Policy Res. Work. Pap. Ser. 2008, 10, 56-78.

37. Wei, W.; Liu, Y.; Dongdong, P. Research on Effects of Population Aging on Industrial Upgrading. China Ind. Econ. 2015, 11, 47-61.

38. Gan, C.H.; Zheng, R.G. An Empirical Study on the Effects of Industrial Structure on Economic Growth and Fluctuations in China. Econ. Res. J. 2011, 46, 4-16.

39. Fu, L.H. An Empirical Research on Industry Structure and Economic Growth. Stat. Res. 2010, $27,79-81$.

40. Guo, S.F.; Pei, Y.L.; Wu, Y.R. Research on Industrial Structure Adjustment and Upgrading Effect of the Development of Productive Service Industry. J. Quant. Tech. Econ. 2020, 37, 45-62.

41. Liu, Z.B. To Promote Industrial Transformation and Upgrading by Urbanization-And on the Historical Affect of "Land Finance" in Transformation Period. Acad. Mon. 2010, 42, 65-70.

42. Fu, Y.; Zhang, Y. Chinese-style decentralization and fiscal expenditure structure bias: The cost of competition for growth. Manag. World 2007, 3, 4-12.

43. Cheng, W.F.; Wei, Z.; Tao, M.W.; Yong, L. Tax, Manipulation to Prices of Intermediate Goods, and the Barriers to Industry Upgrade. China Econ. Q. 2013, 22, 34-46.

44. Sheng, D.; Wang, Y.J. Marketization, Technological Complexity, and Industrial Growth in China's Provinces and Regions. J. World Econ. 2011, 34, 26-47.

45. Wu, F.X.; Shen, H.P. New urbanization, spatial spillover of infrastructure and upgrading of regional industrial structure: An empirical analysis based on 16 core cities in the Yangtze River Delta urban agglomeration. Financ. Econ. 2013, 6, 89-98.

46. $\mathrm{Wu}, \mathrm{N}$.; Liu, Z. Higher education development, technological innovation and industrial structure upgrade. Technol. Forecast. Soc. Chang. 2021, 162, 67-79. [CrossRef]

47. Wu, Z.H. Urbanization, Human Capital Agglomeration and Industrial Structure Adjustment. Reform Econ. Syst. 2020, 11, 59-65.

48. Fang, Y.; Gao, J. An Analysis of FDI's Influence on Industrial Structure-An Empirical Study Based on VEC Model. J. Beijing Technol. Bus. Univ. (Soc. Sci. Ed.) 2010, 25, 49-52.

49. Zhang, H.T.; Li, X. Fiscal Decentralization, Economic Growth and Industrial Structure Imbalance: An Empirical Study Based on Provincial Panel Data. Inq. Econ. Issues 2017, 8, 114-119.

50. Geng, Q.L. The Effects of Changes in Industrial Structure due to Fixed Assets Investment. J. Appl. Stat. Manag. 2010, 29, 1104-1114.

51. Zhang, Z.D.; Li, F.Y. Infrastructure, Spatial Spillover and the Upgrading of Industrial Structure: Based on the Empirical Analysis of Prefecture-level Cities in the Yangtze Economic Belt. J. Yunnan Univ. Financ. Econ. 2019, 35, 55-63. 